\title{
REVIEW
}

UDC 578.1:578.233.7

doi: https://doi.org/10.15407/ubj93.01.005

\section{CORONAVIRUS VIROPORINS: STRUCTURE AND FUNCTION}

\author{
I. ZALOILO ${ }^{1}$, Y. RUD', O. ZALOILO ${ }^{2}$, L. BUCHATSKYI ${ }^{2}$ \\ ${ }^{1}$ National University of Life and Environmental Sciences of Ukraine, Kyiv; \\ ${ }^{2}$ ESC Institute of Biology and Medicine, \\ Taras Shevchenko National University of Kyiv, Ukraine; \\ e-mail: iridolpb@gmail.com
}

Received: 08 July 2020; Accepted: 17 December 2020

Viroporins are involved in viral pathogenesis, play an important role in the morphogenesis of virions and ensure their release from the infected cell. These proteins are potentially promising as possible targets for the regulation of virus reproduction. The literature data on the current understanding of coronavirus viroporins functioning are summarized in the review. Special attention is focused on specific structural features that determine the functional ability of these proteins. The basic principles of viroporins localization in the cell and their influence on the coronavirus life cycle are considered.

Ke y w o rd s: viroporins, coronavirus, protein E, pore formation, protein 3a, protein 8a, SARS.

$\mathrm{V}$ iroporins are small hydrophobic virusinduced proteins capable to modify cellular permeability for ions or other small molecules when interacting with membranes. Possibility of viruses influence on cell membranes was first shown in Ukraine in 70s of last century by the example of influenza virus strain A2-67 [1,2]. The term "viroporin" was first introduced by a group of Spanish virologists in 1993 followed by the fact that similar properties were inherent to several viral proteins [3]. It was later shown that a number of proteins synthesized in virus-infected cells had the ability to change the membranes permeability, providing virions escaping from cells in reality [4].

The presence of viroporins is not a prerequisite for virus replication, but they play an essential role in the life cycle of virus. It has been shown that along with the actual pore-forming properties, viroporins have other important biological functions (participation in virions morphogenesis and viral pathogenesis processes) $[5,6]$.
Viroporins genes have been found in various viral genomes, however they are most often described for RNA-containing viruses, including a number of human pathogens: hepatitis C virus (HCV), HIV1 (HIV-1), influenza virus, poliomyelitis virus, and others, including coronavirus SARS-CoV [7].

Genetic diversity and variability of coronaviruses are provided by high frequency of recombination of genomic RNA, promotes spontaneous appearance of isolates and virus strains with new properties. Thus, tremendous pandemic caused by the previously unknown betacoronavirus SARSCoV-2, that led to COVID-19 diseases, has become a real challenge of our time. The lack of effective means of treatment of this disease indicates the need for intensive research into the structure and functional mechanisms of reproduction of coronaviruses and their structural components, including viroporins.

This work was aimed to summarize the current views on the structure and function of coronavirus

(c) 2021 Zaloilo I. et al. This is an open-access article distributed under the terms of the Creative Commons Attribution License, which permits unrestricted use, distribution, and reproduction in any medium, provided the original author and source are credited. 
viroporins based on existing scientific papers and literature data. Such an examination could be useful for further development of research in this direction and search for practical ways to prevent and overcome coronavirus infections.

\section{Viroporins and other coronavirus proteins}

The coronavirus genome encodes 4 main structural proteins (Fig. 1): E - envelope protein, M membrane protein, $\mathrm{N}$ - nucleocapsid protein, and $\mathrm{S}$ spikes protein [8]. In the mentioned protein complex protein $\mathrm{E}$ is a viroporin, i.e. its function includes the channels formation in a membrane of the affected cell for the preparation of new virions output to the outside.

For a long time, the avaiability of coding of the "E-M-N-S" protein complex was considered a necessary condition for obtaining a complete viral particle. However, in recent years this statement has been disproved: a number of works $[8,9]$ showed full viability of coronavirus in the absence of one of the main structural proteins. Other researchers demonstrate the ability of the viral genome to encode additional proteins, including viroporins. Thus, in different years additional proteins encoded by genome 4a of coronavirus HCoV-229E [10], protein ns12.9 of coronavirus HCoV-OC43 [11], protein $8 \mathrm{a}$ of coronavirus SARS-CoV [12] and others have been discovered.

Most genomes of known coronaviruses encode two or more viroporins, among which the most studied is the conservative protein E. The protein 3a of coronavirus SARS is additional, it is actively examined but is much less studied [12]. Other additional coronavirus proteins, which are also capable of formation (4a, ns12.9, 8a) are practically not studied. Thus, despite the variety of existing forms of viroporins or viroporins proteins, most of their structural and functional features for coronaviruses will be considered below exactly by the example of protein E SARS.

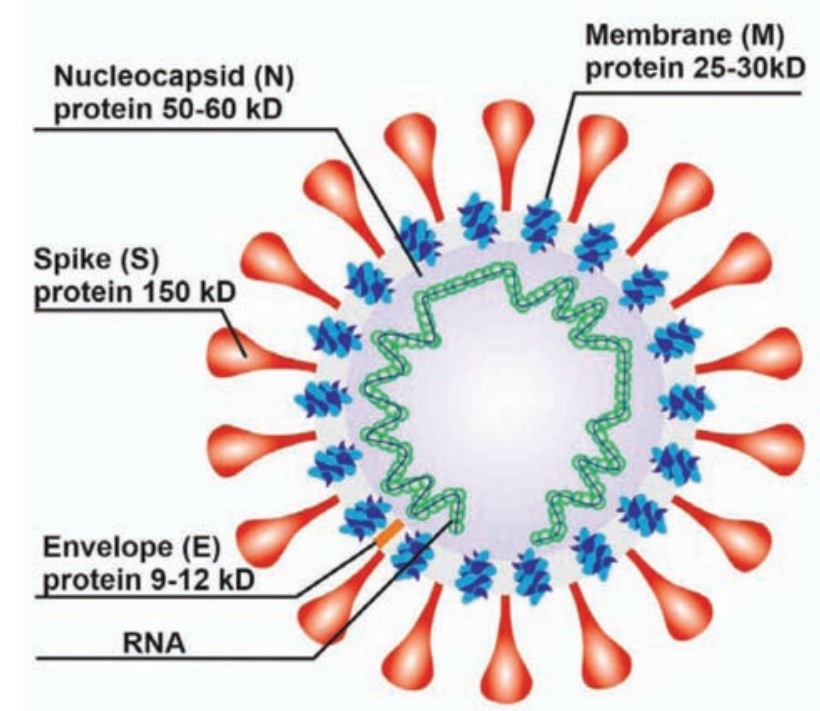

Fig. 1. Scheme of placement of coronavirus basic structural proteins

\section{Viroporins structure}

The size of viroporins is relatively small: they consist of 39-120 amino acid residues and contain at least one area that can be folded into a membrane spiral (the exception is protein 3a, which consists of 274 amino acid residues). Some of these proteins have areas constructed of base or aromatic amino acids. These sites are believed to be in the interfacial area of the membrane [7].

Protein E is the smallest of the complex of coronavirus basic structural proteins. It is a short membrane protein no larger than $12 \mathrm{kDa}$ containing up to 109 amino acids [13]. Molecule E consists of a small hydrophilic amino ends containing 7-12 amino acids followed by a hydrophobic transmembrane domain formed by 25 amino acids. The rest of the molecules are hydrophobic carboxylic end, which makes up the majority of protein [14] (Fig. 2).

As for the secondary structure of this viroporin, the authors of the works $[15,16]$ assert the presence of at least one amphipatic and $\alpha$-helical molecule

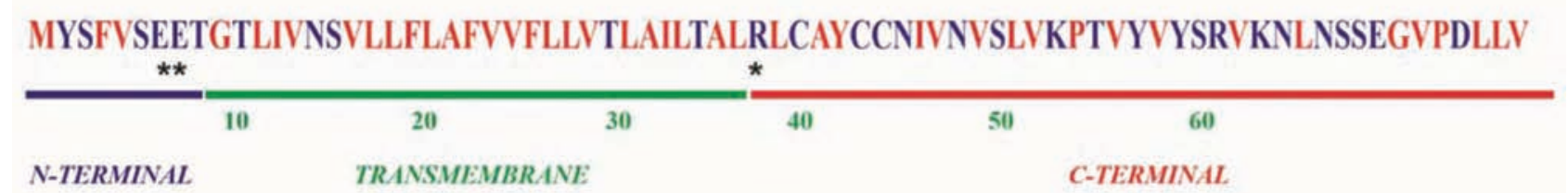

Fig. 2. Amino acid sequence and basic structural components of protein E SARS-CoV E. Amino acid properties: hydrophobic - red, hydrophilic - blue, polar and charged are indicated by stars 
of protein $\mathrm{E}$ in the hydrophobic region of the transmembrane domain. The above assertion is not experimentally proved, but it is considered reliable, because no other rational method of oligomerization with the subsequent formation of the ion channeltime for this structure has been proposed.

Transmembrane domain of protein E molecule is formed from valine and leucine: these neutral amino acids stipulate significant hydrophobic properties of the whole molecule [14]. All the peptide is neutral as well: after all, the middle region of the molecule has no charge, and the negatively charged $\mathrm{N}$-end is mutually compensated on the polarity with the Cterminal, which has a variable charge. In different years it was found the additional structures in protein E molecule, in particular - specific domain PDZ where protein E capable to interact with PDZ structures, which are on carboxylic ends of proteins-targeted organism. Such kind of mechanism promotes optimal development of viral infection [17, 18]. As a "messenger" in the interaction between PDZ coronavirus domains and protein-host is a specific peptide structure of PBM or PDZ-binding motif, being in the structures of protein E. It has been proved the importance of PBM for development and reproduction of coronavirus SARS: in the infected cells, the suppressed or removed RSM domain invariably formed again in its primary structure. By the time this complex was restored, protein E lost the ability to bind with target proteins. Thus, it could be claimed that it is promising to search for ways of serial LMF mutation in order to prevent the development of viral infection. Thus, it can be argued that the search is promising.

The structure of protein 3a is described in [20]. This rather large molecule of $31 \mathrm{kDa}$ consists of 274 amino acid residues. The peculiarity of 3a structure is the presence of three transmembrane domains and a region rich in cysteine, which enabled to speak about possible interactions of $3 \mathrm{a}$ with the main structural protein S (Fig. 3) and even to determine quantitative correlations in such contacts. The $\mathrm{N}$-terminal of the molecule is outside the cell, while the S-terminal is inside the cell [21].

It is interesting that recent studies of the protein 3a SARS CoV-2 structure showed a high level of its similarity (97.82\%) by amino acid sequence with the structural protein NS3 of the bat coronavirus RaTG13, which may be another confirmation of the zoonotic origin of COVID-19 [22].

Another coronavirus viroporin SARS is membrane associated protein 8a, containing 39 amino acids and having in its structure one transmembrane domain with a length of about 22 amino acid residues [23].

Thus, despite its small size, coronavirus viroporins have a rather complex secondary structure, with the help of which virions are formed and affect new cells, or new hosts.

\section{Cell localization}

Protein E is localized in the endoplasmic reticulum (ER), Golgi apparatus (AG) and their vesiculartubular intermediate structures ERGIC (ER-Golgi intermediate compartment) [24, 25]. Such placement is logical, because it is known that coronaviruses (unlike other studied viruses) acquire their membrane envelope in ERGIC structures [26], and virions are released also through ERGIC cavities along the secretory path $[27,28]$. It is worth mentioning that the localization of protein $\mathrm{E}$ was not

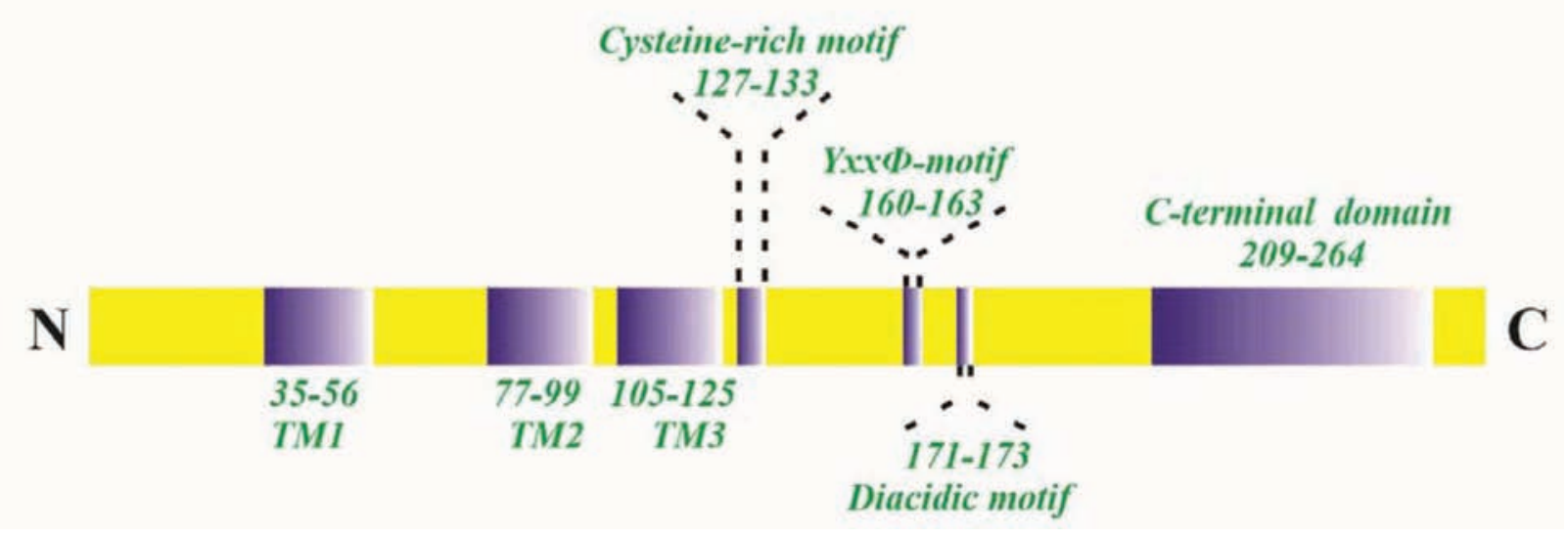

Fig. 3. The structure of viroporin $3 a$ 
considered to be quite reliable for a certain period, because the method of epitopic labeling (FLAG-tag), which was used to study the location of this protein, could influence on the final location of protein in an infected cell. The point is made in [24]: the authors investigated the intracellular localization of SARS CoV E in infected and transfected cells.

The results clearly indicate that epitope labels do not affect the location of this protein in the cell: regardless of the concentration and mode of protein E expression, its prevailing amount is localized in EP and AG. Considering this trend, the search for the region of protein $\mathrm{E}$ molecule, which is informatively responsible for targeting on ERGIC, is obviously promising in the aspect of preventing the development of viral infection. The first steps in the solution of this problem were made in 2002. The authors studying the coronavirus of avian infectious bronchitis (IBV), proved that the direction of protein $\mathrm{E}$ for localization in AG corresponded to the area at the carboxylic end of a protein molecule [29]. Later this structural feature was confirmed also for protein $\mathrm{E}$ of coronavirus SARS [30], though in the latter case the information about targeting was not so clear. The authors of the work claimed that the structures at the $\mathrm{N}$-terminal of protein E corresponded partially to the Golgi complex as well. This mechanism, just like the structure of guiding complexes, remain unknown for the moment.

Viroporin 3a is localized in cytoplasm, and its overwhelming amount is concentrated in Golgi apparatus [31]. The same work shows that this protein can be transported to the cell surface and penetrate it by endocytosis.

\section{Protein-protein interactions}

Interaction with other envelope proteins. A unique property of coronavirus protein $\mathrm{E}$ is its ability to form homotypic interactions. As a result of such mechanisms, oligomerization occurs with the subsequent production of ion channel proteins - viroporins [32]. In 2005, a series of studies were done with the artificially created analogues of SARS coronavirus peptides. As a result, the ability to form oligomertype multimers was recorded only for objects that had a transmembrane domain as close as possible to the natural one. In 2005, a series of studies were fulfilled with artificially created analogues of SARS coronavirus peptides. The result was that the ability to form oligomer-type multimers was recorded only for the objects that had a transmembrane domain as close as possible to the natural one. Thus, we can argue about the importance of the transmembrane domain in the mechanisms of oligomerization of protein $\mathrm{E}$. The same thesis is proposed in [33]: a change in the structure of the transmembrane domain led to the appearance of exclusively monomeric formations. Despite the obvious prospects for finding areas of the middle domain of protein $\mathrm{E}$ that are responsible for homotypic interactions, little research has been carried out in this area. Successes in solving this problem include an experimental attempt to mutate residues of the transmembrane domain of asparagine to alanine and valine to phenylalanine. This approach actually stopped the viroporin activity of the SARS coronavirus [34, 35]. However, the method described above is used only in vitro and cannot be used in medical practice.

Interaction with nucleocapsid proteins. For most coronaviruses, the presence of structural proteins $\mathrm{M}$ and $\mathrm{E}$ is a guarantee of the formation of virus-like particles (VLP). However, a number of studies have shown a significant increase in VLP production in case of parallel expression of nucleocapsid protein $\mathrm{N}$ and protein $\mathrm{E}[8,36]$. It is currently believed that $\mathrm{N}$ and $\mathrm{E}$ proteins interact with $\mathrm{M}$ autonomously, although co-immunoprecipitation of these structural proteins in viral disease has been shown in [37]. However, this interaction has only been studied at transfected sites, so the possibility of physical contact "E-N" remains virtually unconfirmed.

Interaction with spike proteins. Based on the sequence of the SARS coronavirus genome and phylogenetic analysis, similar binding centers of cysteine nature were found in proteins $\mathrm{E}$ and $\mathrm{S}$ : in protein $\mathrm{E}$, this structure was located directly next to the transmembrane domain, but in S - at the carboxyl end of the molecule. The authors believe that the similarity of the binding centers in proteins $\mathrm{E}$ and $\mathrm{S}$ indicates the possibility of association of coat proteins and coronavirus spikes.

In general, the interaction of proteins $S$ and $E$ is currently insufficiently studied. The results of practical studies of such mechanisms were published [38]. The authors, using labeled protein $\mathrm{E}$ of coronavirus SARS, applied the method of tandem affinity purification in combination with mass spectroscopy. It was shown that one of the "partners", which had been purified in conjunction with protein E, was S-protein. This publication registered nothing else but the possibility of interaction of $\mathrm{E}$ and $\mathrm{S}$ proteins without 
further study of this mechanism and its functional significance for the virus viability.

Protein $7 \mathrm{a}$ is localized in mature virions of the coronavirus. It causes apoptosis and cell cycle arrest by stimulating cytokine production [39]. This protein is unique to SARS and is not found in other known coronaviruses. The interactions of proteins $\mathrm{E}$ and $7 \mathrm{a}$ have been proven experimentally in a number of studies, and it is believed that protein 7a does not participate in the replication mechanisms of the SARS coronavirus [22, 40, 41].

Auxiliary viroporin 3a has been shown to interact with all major structural proteins of the coronavirus [42]. Thus, the ability of protein 3a to associate with protein $\mathrm{S}$, as well as their mutual functional correlation, has been experimentally proven [20]. In [43], the interaction of protein 3a with structural proteins $\mathrm{S}$ and $\mathrm{M}$ in the Golgi apparatus, at the sites of collection and isolation of the formed virus was demonstrated. There are many such experimental confirmations of protein-protein interactions involving protein 3a, but they postulate mostly only the very fact of such contacts without explaining the biological role of this viroporin.

Interaction with host proteins. Since viruses have not got their own mechanism of self-reproduction, the process of their reproduction depends entirely on the mechanisms carried out in the infected cell. Thus, it was shown that numerous viruses used the mechanism of replication of the host cell using specific proton pump inhibitors [17]. Regarding the interactions of viral and host proteins, a similar mechanism was first described in 2005 for SARS coronavirus protein $\mathrm{E}$ and antiapoptotic protein $\mathrm{B}$ in lymphoma (Bcl-xL). Subsequently, specific domains were found that are mediators for such interactions [44-46].

In a review [4], the authors discribe 5 host proteins with which the facts of interaction of coronaviral protein $\mathrm{E}$ have been found. In addition to Bcl-xL described above these are PALS1, synthenin, stomatin, sodium-potassium and ATPase $\alpha-1$ subunits. The authors of the relevant studies note usually, in addition to the fact of protein-protein interaction, its biological role. However, most of these statements are hypothetical and despite the high level of argumentation they are mostly not experimentally proven. One of the exceptions could be considered the work [47]. The authors proved in practice the dependence of development rate of coronavirus SARS pathogenesis in vivo on the presence of protein $\mathrm{E}$. The publication gives quantitative indicators of redistribution of syn- thenin in cytoplasm when interacting with protein E, which statistically provokes significantly an excess of inflammatory cytokines.

Such changes can cause an acute immune response that leads to severe respiratory distress with tissue damage and edema.

Apparently, the possible protein-protein interactions of protein $\mathrm{E}$ capable of viroporin activity have been studied very little. Another negative aspect in this situation is that in fact in all the above works, the SARS of coronavirus is used as the protein E object. However, the study of the mechanisms of structural proteins of the envelope of other representatives of coronaviruses is not only interesting from a purely scientific point of view but also promising in terms of finding effective therapeutic pathways for the treatment of coronavirus diseases.

\section{Functions of viroporin proteins}

Modern studies of coronaviruses viroporins enable to identify three functional areas: promoting the collection of viral particles, ensuring the release of virions from the infected cell and participation in viral pathogenesis.

The release of coronavirus virions from the affected cell was preceded by formation of their membranes in ERGIC and movement along the secretory pathway [27, 48]. In formation of the viral envelope, the determining role belongs to the protein $M$. Nevertheless the functional value of protein $\mathrm{E}$ is also essential for this process implementation $[49,50]$. There are a number of similar studies on the development of coronaviruses in removal of protein E gene and in the formation of recombinant virions. The authors [41, 51-53] showed that the absence of envelope protein, although not completely stoped the process of virus reproduction, but significantly inhibited it and with high probability led to structurally defective virions. An extensive review publication [4] analytically confirmed the importance of protein E for virus collection. It was emphasized the need for comprehensive research on this problem. The amount of protein $\mathrm{E}$ in the virion envelopes was very small compared to protein $\mathrm{M}[54,55]$. Initially, protein $\mathrm{E}$ had a purely catalytic role: it was thought viral particles separat from the endoplasmic reticulum in the terminal phase [56]. However after a while, much more important functions were shown for this protein.

Studies (mostly electron microscopic) have been conducted in different years to prove the abili- 
ty of protein $\mathrm{M}$ to deform membranes on its own, but practical results have refuted this assumption: without protein E, recombinant viral particles showed significant morphological abnormalities. Thus, when mutating the carboxyl end in molecule protein $\mathrm{E}$ of hepatitis $\mathrm{M}$ virus, the produced virions not only changed from typical spherical to oblong in shape, but also acquired significant sensitivity to temperature [57]. Upon removal of protein E gene in recombinant SARS coronavirus, the host cell infected with it contained a small number of virions against numerous vesicular formations with a dense filling of unknown composition in the form of granules. The authors [58] seem to consider such vesicles as immature virions, which are formed as a result of an interrupted cycle of virion formation. Similar situation was observed in case of deprivation of protein $\mathrm{E}$ in swine transmission gastroenteritis virus (coronavirus TGEV): immature virions were also observed in the infected cell, but they were not yet able to move secretory [59]. The authors [4] believe that such effects indicate the induction by protein $\mathrm{E}$ of bending of a viral envelope membrane, which ultimately causes the virions to acquire a natural spherical shape.

Additional coronavirus proteins SARS 3a and 8a do not participate at all, or they play a minor role in virions formation. In $[11,60]$ and many others, studies of the development of coronavirus disease during the removal of genes encoding viporins $3 \mathrm{a}$ and 8a have been demonstrated. The consequence of such experiments was a decrease in the number of released virions in the probable absence of changes in viral reproduction.

The most studied function of viroporins is to modify the degree of permeability of the cell membrane for ions and small soluble substances. The first studies on the viruses effects on cell membranes appeared long before the practical identification of viroporins $[1,2]$. In the light of modern ideas, it could be argued that viporins are at least partially responsible for this effect, especially at the end of the virus replication cycle. These small proteins are predominantly hydrophobic in nature. They oligomerize in a membranes of the infected cells, forming hydrophilic pores. The hydrophobic residues are located outside these channel formations, and the inner part of the pore contains hydrophilic residues [61-62]. The studied viporins have certain structural features. For example, protein $\mathrm{E}$ is characterized by the presence of an amphipathic $\alpha$-helix in a molecule hy- drophobic domain: such a structure in combination with positively charged amino acids in molecular composition enables to fix a pore on the membrane by purely electrostatic interactions with negatively charged phospholipids [63-64].

In most cases, the ion channels formed by viporins are nonselective or low-selective for certain ions or small molecules. However, some examples demonstrate significant selectivity: for example, the influenza A M2 protein [65] is highly selective for protons and active at low $\mathrm{pH}$, and the $\mathrm{Kcv}$ protein of chlorella virus is selective for potassium ions [66]. In general, viroporins are able to transfer various ions, but mostly they are positively charged particles: hydrogen, calcium, sodium, potassium [67]. Along with cationic permeability, viroporins can also transport anions. In some cases, the selectivity of viroporins may vary depending on environmental conditions. Thus, it was shown that when the acidity of the medium approaches neutral values, the poreforming protein SH of human respiratory syncytial virus (HRSV) changes its selectivity from cationic to anionic [68]. Well-studied protein M2 of influenza A virus is generally regulated by $\mathrm{pH}$ medium: its activation is observed at deviation into the "acidic" region [69].

The unique mechanism of changing the permeability of a cell membrane is demonstrated by protein E of SARS-CoV coronavirus: in oligomerization process it forms pores that integrate membrane lipids, which polar groups affect the ions selectivity. The loss of membrane polarization could promote the virus release through differing mechanisms that operate throughout the virus life cycle. In viral envelopes, viporins are contained in small concentrations, however, their presence can further contribute to the entry of the virus into a cell.

The research results of protein E pore-forming properties at structural level have been described in numerous studies, and the information on the structure of coronaviruses viroporins was obtained using artificially synthesized peptides of SARS coronavirus [70-72]. This approach enables to claim today that the ion-conducting properties of protein $\mathrm{E}$ are responsible for the transmission domain: it undergoes oligomerization inherent in ion-channel proteins. As a result of such transformation, a stable pentamer is formed [32], capable of pore formation. In [73], on the example of protein E of swine reproductive and respiratory syndrome (PRRSV), it was shown that mutation of cysteine residues is 
not necessary for oligomerization of viroporin. This suggests that the formation of viroporin is not due to disulfide bonds, but to ionic interactions. Since the transmission domain of protein $\mathrm{E}$ has pronounced hydrophobic nature, direct studies of the principles of viporin formation are extremely difficult in practice. Therefore, mutation techniques and ion channel inhibitors, such as amantadine, are mainly used for such experiments.

In terms of selectivity, protein E "prefers" monovalent sodium and potassium ions. Synthetic peptides E of SARS are also capable of transferring chlorine ions, although the selectivity for this ion is the lowest. Artificial analogues of human E coronavirus protein (HCoV-229E), murine hepatitis virus (MHV), and avian infectious bronchitis virus (IBV) show the same selective features [70]. Subsequently, the results of studies on artificial peptides E of SARS were repeated using a full-length molecule - the obtained results of selectivity differed slightly [34]. Several years ago, an attempt was made to study the full-length E molecule of the Middle Eastern Respiratory Syndrome virus (MERS-CoV) the results showed limited selectivity of viroporin as well, but they were mostly general [74]. During the same period, the ability of viroporin to transport calcium ions was demonstrated for the first time with the use of artificial peptides E of SARS coronavirus [75]. The authors associated this property with the inflammatory response to the development of severe acute respiratory syndrome. Viroporins were originally thought to form a primitive ion channel in the cell membrane as a result of intrinsic oligomerization. However SARS coronavirus protein $\mathrm{E}$ has been shown to form complex channels, which structure contains additionally host cell lipids [60] (Fig. 4).

The importance of viroporins in ensuring the release of virions from the infected cell is without any doubt, but the role of activity of host cell proteins in ion channels remains unknown despite numerous works in this direction [76-77]. Several years ago it was shown that in cells infected by IBV and transfected with virus cDNA, there was a significant increase of $\mathrm{pH}$ in the area of ERGIC [78]. It should be noted that this feature was observed in the expression of monomeric forms of protein $\mathrm{E}$, and in the expression of oligomeric forms required for the formation of viroporin, $\mathrm{pH}$ fluctuated slightly. The authors suggest that $\mathrm{E}$ monomers are able to interact with a specific protein of an infected cell. Thus, it is possible that the host protein may play a key role in the process of oligomerization of protein $\mathrm{E}$.

Viroporin 3a forms a homotetrameric complex using disulfide bridges and thus it forms a channel with increased permeability to potassium [79]. In the same work, the described channels were blocked by barium, which led to a decrease in the number of released virions at constant intensity of viral replication.

In 2011, the ability to form ion channels in artificial lipid bilayers with increasing temperature to $+38.5^{\circ} \mathrm{C}$ was shown for additional coronavirus protein $8 \mathrm{a}[80]$. The authors claim that the main function of this protein is to enhance coronavirus replication.

Thus, fluctuations in the selectivity of viroporins in response to changes in $\mathrm{pH}$ and temperature indicate their sensitivity to environmental factors. Knowledge of pore formation and the mechanisms that precede it, as well as the consequences of ion channels for viral reproduction remain incomplete.

\section{Influence of viroporins on coronavirus reproduction}

The effect of murine hepatitis E virus (MHV) [84] and coronavirus SARS on the endoplasmic reticulum has been studied in different years [85]. In
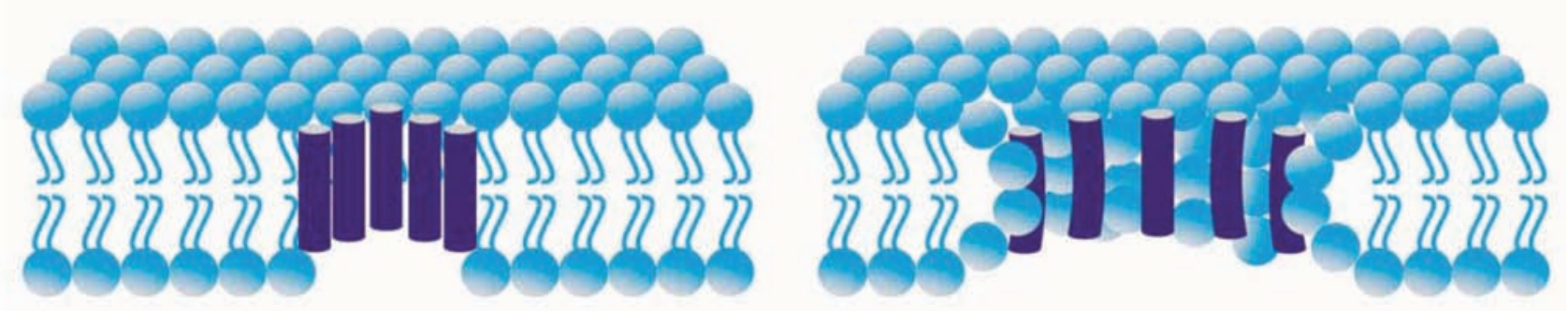

Fig. 4. Ionic channels formed by viroporins: on the left - the channel formed by protein monomers; rightprotein-lipid pore (lipid) heads are oriented in the direction of the channel, modulating its ionic conductivity and selectivity 
both cases, the viral envelope protein showed the ability to induce apoptosis.

However, removal of the SARS coronavirus protein gene $\mathrm{E}$ caused apoptosis more efficiently compared to exposure to a natural viral particle. In [86], this correlation is explained by the ability of protein $\mathrm{E}$ to regulate the response of the expanded protein (RRB), as a response of the reticulum to stress, which is a form of antiviral response [81-83].

The endoplasmic reticulum is a fairly stable structure that can withstand significant protein loads without functional changes. However, with a significant excess of proteins, this organelle partially loses the ability to coagulate protein molecules, and in its intervals such proteins begin to accumulate, having a defective or completely absent secondary structure [81]. In this situation, there is a characteristic response of the reticulum to stress, called the reaction of expanded protein (RRB) - a violation of protein folding, aimed at stimulating the coagulation of organelles. In some cases, the duration of such a reaction can be significant, leading to irreversible consequences and the initiation of apoptosis [82]. As a result, a cell loses its functionality and is likely to die. A number of viral infections can act as stimulators of RRB. So in some cases, the response of the endoplasmic reticulum to stress is a form of antiviral response [83].

It is known that coronaviruses can encode proteins capable of regulating the immune response (enhancement or suppression - depending on pathogenicity). A typical example of such mechanisms is activation of the inflammatory process by E protein of swine reproductive syndrome virus [87]. The authors showed a clear relationship between inflammation and protein $\mathrm{E}$ activity by comparing the natural development of infection with a model system where protein $\mathrm{E}$ functions were blocked by amantadine. In the latter case, the inflammatory processes were significantly smaller. Recently, similar experiments have been repeated for infectious bronchitis virus [88]. The results of studies confirmed the ability of protein $\mathrm{E}$ to regulate the immune response and the response of the endoplasmic reticulum to stress.

Antibodies to protein 3a are easily detected in patients recovering from SARS [89]. Immunization of rabbits with a synthetic peptide corresponding to amino acids 15-28 from the N-terminus of protein $3 \mathrm{a}$ results in the induction of neutralizing antibodies that inhibit SARS-CoV infection in cells [90]. Several studies have focused on the biological func- tions of protein 3a primarily through expression in transplanted cell cultures. In vitro expression studies in cultured cells have shown that protein 3a induces arrest of the G1 phase of the cell cycle by reducing cyclin D3 expression and inhibiting retinoblastoma $(\mathrm{Rb})$ protein phosphorylation [91], and induces apoptosis in Vero E6 cells [92]. The role of cell arrest and apoptosis in the life cycle of SARS-CoV remains unclear.

Recently, SARS coronavirus protein 3a has been shown to activate the inflammatory response of the NLRP3 domain in macrophages containing lipopolysaccharides, influencing the release of potassium and reactive forms of mitochondrial oxygen [93]. Another study demonstrates the ability of the SARS-CoV open reading frame 3a (ORF3a) helper protein to activate inflammation of the NLRP3 domain by stimulating receptor-associated factor 3 TNF [94].

Viroporin 8a is capable of inducing apoptosis through the mitochondrial-dependent pathway [23]. On the other hand, the effect of viroporin 8a on the development of coronavirus SARS-MA15 was studed recently [12]. These results call the significance of the effect of this viroporin on virulence in question. Thus, the biological functions of 8a remain poorly understood.

Conclusion. Active research in biology of the family Coronaviridae members began in 2002 after the epidemic of severe acute respiratory syndrome (SARS) in Asian countries. Despite the rather extensive information about the causative agent of this disease, the coronavirus SARS-CoV-1, effective treatments have not been created. Existing drugs are powerless against SARS and are aimed only at relieving its symptoms and surgical rehabilitation of the body in case of recovery. This thesis is confirmed in the modern world: the SARS-CoV-2 pandemic, which began in December 2019, has reached catastrophic proportions in much of the planet.

The zoonotic origin of SARS and numerous data indicate the presence of similar viruses in bats indicate a fairly high probability of new human coronavirus diseases in the future. It is obvious that this situation indicates the priority nature of research on coronaviruses, aimed primarily at effective treatment and prevention of infections.

The functional role of viroporins in the life cycle of the virus remains poorly understood. Most of the confirmed data are obtained only for the main structural protein E of the SARS-Cov-2 or 1. Howe- 
ver, even the small amount of information available today indicates the potential prospects of viroporins as possible targets for the reproduction and spread of viruses. The main function of such proteins is the formation of ion channels in the membrane of the infected cell, which makes it permeable to virions and ensures the release of new viral particles into the extracellular space. However, the functional role of viroporins is not limited to pore-forming properties: these proteins play a significant role in the mechanisms of formation of new viral particles and in various aspects of pathogenicity. Inhibition of these proteins or blocking their activity at the body level could be a real method of overcoming outbreaks of coronaviral diseases. Effective control of viroporins requires the fullest possible understanding of their structure and the mechanisms in which these proteins are directly involved.

Conflict of interest. Authors have completed the Unified Conflicts of Interest form at http://ukrbiochemjournal.org/wp-content/uploads/2018/12/ coi_disclosure.pdf and declare no conflict of interest.

Funding. The research was carried out within the framework of the research project "Preclinical studies of melanin toxicity - substances for new drugs and the effectiveness of dermatotropic drugs based on nanoparticles" (Registration number 16БП036-04).

\section{ВІРОПОРИНИ КОРОНАВІРУСІВ: СТРУКТУРА І ФУНКЦІї}

\section{І. А. Залоїло1, Ю. П. Рудь ${ }^{2}$ О. В. Залоїло ${ }^{2}$, Л. П. Бучачький}

\author{
${ }^{1}$ Національний університет біоресурсів \\ і природокористування України, Київ; \\ ${ }^{2}$ ННЦ «Інститут біології та медицини», \\ Київський національний університет \\ імені Тараса Шевченка, Україна; \\ e-mail: iridolpb@gmail.com
}

Віропорини беруть участь у вірусному патогенезі, відіграють важливу роль у морфогенезі віріонів та забезпечують їх вивільнення з інфікованої клітини. Ці протеїни $€$ потенційно перспективними як можливі мішені для регулювання репродукції вірусів. В огляді узагальнено літературні дані щодо сучасного розуміння функціонування віропоринів. Особливу увагу зосереджено на специфічних структурних особливостях, які обумовлюють функціональну спроможність цих протеїнів. Розглянуто основні принципи локалізації віропоринів у клітині та їх вплив на життєвий цикл коронавірусів.

К л ю ч о в і с лов а: віропорини, коронавірус, протеїн Е, пороутворення, протеїн 3a, протеїн 8a, SARS.

\section{References}

1. Buchatsky LP. The effect of influenza A2-67 virus on the membrane potential of cells of the chick embryo chorionallantois membranes. Mikrobiol Zh. 1972; 34(1): 71-73. (In Ukrainian).

2. Buchatsky LP, Kaplunenko MO. Influence of the A268 influenza virus and its Vi-antigen on the membrane potential of chorionicallantoic membranes of chicken embryos. Mikrobiol Zh. 1973; 35(2): 206-209.

3. Carrasco L, Perez L, Irurzun A, Martinez-Abarca F, Rodriguez P, Guinea R, Castrillo JL, Sanz MA, Ayala MJ. Regulation of Gene Expression in Animal Viruses. Plenum, New York. 1993. P. 283-303.

4. Schoeman D, Fielding BC. Coronavirus envelope protein: current knowledge. Virol J. 2019; 16(1): 69.

5. Satarker S, Nampoothiri M. Structural Proteins in Severe Acute Respiratory Syndrome Coronavirus-2. Arch Med Res. 2020; 51(6): 482-491.

6. Farag NS, Breitinger U, Breitinger HG, El Azizi MA. Viroporins and inflammasomes: A key to understand virus-induced inflammation. Int J Biochem Cell Biol. 2020; 122: 105738.

7. Nieva JL, Madan V, Carrasco L. Viroporins: structure and biological functions. Nat Rev Microbiol. 2012; 10(8): 563-574.

8. Wang C, Zheng X, Gai W, Zhao Y, Wang H, Wang H, Feng N, Chi H, Qiu B, Li N, Wang T, Gao Y, Yang S, Xia X. MERS-CoV virus-like particles produced in insect cells induce specific humoural and cellular imminity in rhesus macaques. Oncotarget. 2017; 8(8): 12686-12694.

9. Siu YL, Teoh KT, Lo J, Chan CM, Kien F, Escriou N, Tsao SW, Nicholls JM, Altmeyer R, Peiris JSM, Bruzzone R, Nal B. The M, E, and N structural proteins of the severe acute respiratory syndrome coronavirus are required for efficient assembly, trafficking, and release of virus-like particles. $J$ Virol. 2008; 82(22): 11318-11330.

10. Zhang R, Wang K, Lv W, Yu W, Xie S, Xu K, Schwarz W, Xiong S, Sun B. The ORF4a protein of human coronavirus 229E functions as a viroporin that regulates viral production. Biochim Biophys Acta. 2014; 1838(4): 1088-1095.

11. Zhang R, Wang K, Ping X, Yu W, Qian Z, Xiong S, Sun B. The ns12.9 Accessory Protein of Human Coronavirus OC43 Is a Viroporin Involved in Virion 
Morphogenesis and Pathogenesis. J Virol. 2015; 89(22): 11383-11395.

12. Castaño-Rodriguez C, Honrubia JM, GutiérrezÁlvarez JL, DeDiego M, Nieto-Torres JL, JimenezGuardeño JM, Regla-Nava JA, FernandezDelgado R, Verdia-Báguena C, Queralt-Martín M, Kochan G, Perlman S, Aguilella VM, Sola I, Enjuanes L. Role of Severe Acute Respiratory Syndrome Coronavirus Viroporins E, 3a, and 8a in Replication and Pathogenesis. mBio. 2018; 9(3): e02325-e02317.

13. Kuo L, Hurst KR, Masters PS. Exceptional flexibility in the sequence requirements for coronavirus small envelope protein function. J Virol. 2007; 81(5): 22492262.

14. Wu Q, Zhang Y, Lü H, Wang J, He X, Liu Y, Ye C, Lin W, Hu J, Ji J, Xu J, Ye J, Hu Y, Chen W, Li S, Wang J, Wang J, Bi S, Yang H. The E protein is a multifunctional membrane protein of SARS-CoV. Genomics Proteomics Bioinformatics. 2003; 1(2): 131-144.

15. Verdiá-Báguena C, Nieto-Torres JL, Alcaraz A, Dediego ML, Enjuanes L, Aguilella VM. Analysis of SARS-CoV E protein ion channel activity by tuning the protein and lipid charge. Biochim Biophys Acta. 2013; 1828(9): 2026-2031.

16. Nieto-Torres JL, DeDiego ML, Verdiá-Báguena C, Jimenez-Guardeño JM, Regla-Nava JA, FernandezDelgado R, Castaño-Rodriguez C, Alcaraz A, Torres J, Aguilella VM, Enjuanes L. Severe acute respiratory syndrome coronavirus envelope protein ion channel activity promotes virus fitness and pathogenesis. PLoS Pathog. 2014; 10(5): e1004077.

17. Javier RT, Rice AP. Emerging theme: cellular PDZ proteins as common targets of pathogenic viruses. $J$ Virol. 2011; 85(22): 11544-11556.

18. Gerek ZN, Keskin O, Ozkan SB. Identification of specificity and promiscuity of PDZ domain interactions through their dynamic behavior. Proteins. 2009; 77(4): 796-811.

19. Jimenez-Guardeño JM, Regla-Nava JA, NietoTorres JL, DeDiego ML, Castaño-Rodriguez C, Fernandez-Delgado R, Perlman S, Enjuanes L. Identification of the Mechanisms Causing Reversion to Virulence in an Attenuated SARS-CoV for the Design of a Genetically Stable Vaccine. PLoS Pathog. 2015; 11(10): e1005215.

20. Zeng R, Yang RF, Shi MD, Jiang MR, Xie YH, Ruan HQ, Jian XS, Shi L, Zhou H, Zhang L, Wu XD, Lin Y, Ji YY, Xiong L, Jin Y, Dai EH, Wang XY, Si BY, Wang J, Wang HX, Wang CE, Gan YH, Li YC, Cao JT, Zuo JP, Shan SF, Xie E, Chen SH, Jiang ZQ, Zhang X, Wang Y, Pei G, Sun B, $\mathrm{Wu}$ JR. Characterization of the 3a protein of SARSassociated coronavirus in infected vero E6 cells and SARS patients. J Mol Biol. 2004; 341(1): 271-279.
21. Liu DX, Fung TS, Chong KK, Shukla A, Hilgenfeld R. Accessory proteins of SARS-CoV and other coronaviruses. Antiviral Res. 2014; 109: 97-109.

22. Issa E, Merhi G, Panossian B, Salloum T, Tokajian S. SARS-CoV-2 and ORF3a: Nonsynonymous Mutations, Functional Domains, and Viral Pathogenesis. mSystems. 2020; 5(3): e00266-20.

23. Guan Y, Zheng BJ, He YQ, Liu XL, Zhuang ZX, Cheung CL, Luo SW, Li PH, Zhang LJ, Guan YJ, Butt KM, Wong KL, Chan KW, Lim W, Shortridge KF, Yuen KY, Peiris JSM, Poon LLM. Isolation and characterization of viruses related to the SARS coronavirus from animals in southern China. Science. 2003; 302(5643): 276-278.

24. Nieto-Torres JL, Dediego ML, Alvarez E, JiménezGuardeño JM, Regla-Nava JA, Llorente M, Kremer L, Shuo S, Enjuanes L. Subcellular location and topology of severe acute respiratory syndrome coronavirus envelope protein. Virology. 2011; 415(2): 69-82.

25. Yuan Q, Liao Y, Torres J, Tam JP, Liu DX. Biochemical evidence for the presence of mixed membrane topologies of the severe acute respiratory syndrome coronavirus envelope protein expressed in mammalian cells. FEBS Lett. 2006; 580(13): 31923200.

26. Hogue BG, Machamer CE. Coronavirus structural proteins and virus assembly. Nidoviruses: American Society of Microbiology. 2008; 179-200.

27. Westerbeck JW, Machamer CE. A Coronavirus E Protein Is Present in Two Distinct Pools with Different Effects on Assembly and the Secretory Pathway. J Virol. 2015; 89(18): 9313-9323.

28. Ruch TR, Machamer CE. The coronavirus E protein: assembly and beyond. Viruses. 2012; 4(3): 363-382.

29. Corse E, Machamer CE. The cytoplasmic tail of infectious bronchitis virus E protein directs Golgi targeting. J Virol. 2002; 76(3): 1273-1284.

30. Cohen JR, Lin LD, Machamer CE. Identification of a Golgi complex-targeting signal in the cytoplasmic tail of the severe acute respiratory syndrome coronavirus envelope protein. J Virol. 2011; 85(12): 5794-5803.

31. Yu CJ, Chen YC, Hsiao CH, Kuo TC, Chang SC, Lu CY, Wei WC, Lee CH, Huang LM, Chang MF, Ho HN, Lee FJS. Identification of a novel protein 3a from severe acute respiratory syndrome coronavirus. FEBS Lett. 2004; 565(1-3): 111-116.

32. Pervushin K, Tan E, Parthasarathy K, Lin X, Jiang FL, Yu D, Vararattanavech A, Soong TW, Liu DX, Torres J. Structure and inhibition of the SARS coronavirus envelope protein ion channel. PLoS Pathog. 2009; 5(7): e1000511.

33. Liao Y, Yuan Q, Torres J, Tam JP, Liu DX. Biochemical and functional characterization of the membrane association and membrane permeabilizing activity of the severe acute respiratory syndrome coronavirus envelope protein. Virology. 2006; 349(2): 264-275. 
34. Verdiá-Báguena C, Nieto-Torres, Alcaraz A, DeDiego ML, Torres J, Aguilella VM, Enjuanes L. Coronavirus E protein forms ion channels with functionally and structurally-involved membrane lipids. Virology. 2012; 432(2): 485-494.

35. Torres J, Parthasarathy K, Lin X, Saravanan R, Kukol A, Liu DX. Model of a putative pore: the pentameric alpha-helical bundle of SARS coronavirus E protein in lipid bilayers. Biophys $J$. 2006; 91(3): 938-947.

36. Hsieh PK, Chang SC, Huang CC, Lee TT, Hsiao CW, Kou YH, Chen IY, Chang CK, Huang TH, Chang MF. Assembly of severe acute respiratory syndrome coronavirus RNA packaging signal into virus-like particles is nucleocapsid dependent. J Virol. 2005; 79(22): 13848-13855.

37. Maeda J, Maeda A, Makino S. Release of coronavirus E protein in membrane vesicles from virus-infected cells and E protein-expressing cells. Virology. 1999; 263(2): 265-272.

38. Alvarez E, DeDiego ML, Nieto-Torres JL, JiménezGuardeño JM, Marcos-Villar L, Enjuanes L. The envelope protein of severe acute respiratory syndrome coronavirus interacts with the non-structural protein 3 and is ubiquitinated. Virology. 2010; 402(2): 281291.

39. Tan YJ, Fielding BC, Goh PY, Shen S, Tan THP, Lim SG, Hong W. Overexpression of 7a, a protein specifically encoded by the severe acute respiratory syndrome coronavirus, induces apoptosis via a caspase-dependent pathway. J Virol. 2004; 78(24): 14043-14047.

40. Schaecher SR, Touchette E, Schriewer J, Buller RM, Pekosz A. Severe acute respiratory syndrome coronavirus gene 7 products contribute to virusinduced apoptosis. J Virol. 2007; 81(20): 1105411068 .

41. Dediego ML, Pewe L, Alvarez E, Rejas MT, Perlman S, Enjuanes L. Pathogenicity of severe acute respiratory coronavirus deletion mutants in hACE-2 transgenic mice. Virology. 2008; 376(2): 379-389.

42. Tan YJ, Teng E, Shen S, Tan THP, Goh PY, Fielding BC, Ooi EE, Tan HC, Lim SG, Hong W. A novel severe acute respiratory syndrome coronavirus protein, U274, is transported to the cell surface and undergoes endocytosis. J Virol. 2004; 78(13): 67236734.

43. Yuan X, Li J, Shan Y, Yang Z, Zhao Z, Chen B, Yao Z, Dong B, Wang S, Chen J, Cong Y. Subcellular localization and membrane association of SARSCoV 3a protein. Virus Res. 2005; 109(2): 191-202.

44. Subramani C, Nair VP, Anang S, Mandal SD, Pareek M, Kaushik N, Srivastava A, Saha S, Shalimar, Nayak B, Ranjith-Kumar CT, Surjit M. Host-Virus Protein Interaction Network Reveals the Involvement of Multiple Host Processes in the Life
Cycle of Hepatitis E Virus. mSystems. 2018; 3(1): e00135-17.

45. Lu J, Qu Y, Liu Y, Jambusaria R, Han Z, Ruthel G, Freedman BD, Harty RN. Host IQGAP1 and Ebola virus VP40 interactions facilitate virus-like particle egress. J Virol. 2013; 87(13): 7777-7780.

46. Teoh KT, Siu YL, Chan WL, Schlüter MA, Liu CJ, Peiris JSM, R Bruzzone, Margolis B, Nal B. The SARS coronavirus E protein interacts with PALS1 and alters tight junction formation and epithelial morphogenesis. Mol Biol Cell. 2010; 21(22): 38383852.

47. Jimenez-Guardeño JM, Nieto-Torres JL, DeDiego ML, Regla-Nava JA, Fernandez-Delgado R, Castaño-Rodriguez C, Enjuanes L. The PDZbinding motif of severe acute respiratory syndrome coronavirus envelope protein is a determinant of viral pathogenesis. PLoS Pathog. 2014; 10(8): e1004320.

48. Krijnse-Locker J, Ericsson M, Rottier PJ, Griffiths G. Characterization of the budding compartment of mouse hepatitis virus: evidence that transport from the RER to the Golgi complex requires only one vesicular transport step. J Cell Biol. 1994; 124(1-2): 55-70.

49. Arndt AL, Larson BJ, Hogue BG. A conserved domain in the coronavirus membrane protein tail is important for virus assembly. J Virol. 2010; 84(21): 11418-11428.

50. Lim KP, Liu DX. The missing link in coronavirus assembly. Retention of the avian coronavirus infectious bronchitis virus envelope protein in the pre-Golgi compartments and physical interaction between the envelope and membrane proteins. J Biol Chem. 2001; 276(20): 17515-17523.

51. Almazán F, DeDiego ML, Sola I, Zuñiga S, NietoTorres JL, Marquez-Jurado S, Andrés G, Enjuanes L. Engineering a replication-competent, propagationdefective Middle East respiratory syndrome coronavirus as a vaccine candidate. mBio. 2013; 4(5): e00650-e00613.

52. Ortego J, Escors D, Laude H, Enjuanes L. Generation of a replication-competent, propagation-deficient virus vector based on the transmissible gastroenteritis coronavirus genome. J Virol. 2002; 76(22): 1151811529.

53. Curtis KM, Yount B, Baric RS. Heterologous gene expression from transmissible gastroenteritis virus replicon particles. J Virol. 2002; 76(3): 1422-1434.

54. Yu X, Bi W, Weiss SR, Leibowitz JL. Mouse hepatitis virus gene $5 \mathrm{~b}$ protein is a new virion envelope protein. Virology. 1994; 202(2): 1018-1023.

55. Nugent T, Jones DT. Transmembrane protein topology prediction using support vector machines. BMC Bioinformatics. 2009; 10: 159.

56. Vennema H, Godeke GJ, Rossen JW, Voorhout WF, Horzinek MC, Opstelten DJ, Rottier PJ. Nucleocapsid- 
independent assembly of coronavirus-like particles by co-expression of viral envelope protein genes. EMBO J. 1996; 15(8): 2020-2028.

57. Fischer F, Stegen CF, Masters PS, Samsonoff WA. Analysis of constructed E gene mutants of mouse hepatitis virus confirms a pivotal role for $\mathrm{E}$ protein in coronavirus assembly. $J$ Virol. 1998; 72(10): 78857894.

58. DeDiego ML, Alvarez E, Almazán F, Rejas MT, Lamirande E, Roberts A, Shieh WJ, Zaki SR, Subbarao K, Enjuanes L. A severe acute respiratory syndrome coronavirus that lacks the $\mathrm{E}$ gene is attenuated in vitro and in vivo. J Virol. 2007; 81(4): 1701-1713.

59. Ortego J, Ceriani JE, Patiño C, Plana J, Enjuanes L. Absence of $\mathrm{E}$ protein arrests transmissible gastroenteritis coronavirus maturation in the secretory pathway. Virology. 2007; 368(2): 296-308.

60. Nieto-Torres JL, Verdiá-Báguena C, CastañoRodriguez C, Aguilella VM, Enjuanes L. Relevance of Viroporin Ion Channel Activity on Viral Replication and Pathogenesis. Viruses. 2015; 7(7): 3552-3573.

61. Melton JV, Ewart GD, Weir RC, Board PG, Lee E, Gage PW. Alphavirus 6K proteins form ion channels. J Biol Chem. 2002; 277(49): 46923-46931.

62. Ye Y, Hogue BG. Role of the coronavirus E viroporin protein transmembrane domain in virus assembly. $J$ Virol. 2007; 81(7): 3597-3607.

63. Gonzalez ME, Carrasco L. Viroporins. FEBS Lett. 2003; 552(1): 28-34.

64. Hyser JM, Estes MK. Pathophysiological Consequences of Calcium-Conducting Viroporins. Annu Rev Virol. 2015; 2(1): 473-496.

65. Thomaston JL, Alfonso-Prieto M, Woldeyes RA, Fraser JS, Klein ML, Fiorin G, DeGrado WF. High-resolution structures of the M2 channel from influenza A virus reveal dynamic pathways for proton stabilization and transduction. Proc Natl Acad Sci USA. 2015; 112(46): 14260-14265.

66. Hu L, Crawford SE, Hyser JM, Estes MK, Prasad BV. Rotavirus non-structural proteins: structure and function. Curr Opin Virol. 2012; 2(4): 380-388.

67. Mould JA, Paterson RG, Takeda M, Ohigashi Y, Venkataraman P, Lamb RA, Pinto LH. Influenza $\mathrm{B}$ virus BM2 protein has ion channel activity that conducts protons across membranes. Dev Cell. 2003; 5(1): 175-184.

68. Li Y, To J, Verdià-Baguena C, Dossena S, Surya W, Huang M, Paulmichl M, Liu DX, Aguilella VM, Torres J. Inhibition of the human respiratory syncytial virus small hydrophobic protein and structural variations in a bicelle environment. J Virol. 2014; 88(20): 11899-11914.

69. Schnell JR, Chou JJ. Structure and mechanism of the M2 proton channel of influenza A virus. Nature. 2008; 451(7178): 591-595.
70. Wilson L, Gage P, Ewart G. Hexamethylene amiloride blocks $\mathrm{E}$ protein ion channels and inhibits coronavirus replication. Virology. 2006; 353(2): 294306.

71. Parthasarathy K, Ng L, Lin X, Liu DX, Pervushin K, Gong X, Torres J. Structural flexibility of the pentameric SARS coronavirus envelope protein ion channel. Biophys J. 2008; 95(6): L39-L41.

72. Torres J, Maheswari U, Parthasarathy K, Ng L, Liu DX, Gong X. Conductance and amantadine binding of a pore formed by a lysine-flanked transmembrane domain of SARS coronavirus envelope protein. Protein Sci. 2007; 16(9): 2065-2071.

73. Lee C, Yoo D. Cysteine residues of the porcine reproductive and respiratory syndrome virus small envelope protein are non-essential for virus infectivity. J Gen Virol. 2005; 86(Pt 11): 3091-3096.

74. Surya W, Li Y, Verdià-Bàguena C, Aguilella VM, Torres J. MERS coronavirus envelope protein has a single transmembrane domain that forms pentameric ion channels. Virus Res. 2015; 201: 61-66.

75. Nieto-Torres JL, Verdiá-Báguena C, JimenezGuardeño JM, Regla-Nava JA, Castaño-Rodriguez C, Fernandez-Delgado R, Torres J, Aguilella VM, Enjuanes L. Severe acute respiratory syndrome coronavirus E protein transports calcium ions and activates the NLRP3 inflammasome. Virology. 2015; 485: 330-339.

76. Hsu K, Han J, Shinlapawittayatorn K, Deschenes I, Marbán E. Membrane potential depolarization as a triggering mechanism for Vpu-mediated HIV-1 release. Biophys J. 2010; 99(6): 1718-1725.

77. Wozniak AL, Griffin S, Rowlands D, Harris M, Yi M, Lemon SM, Weinman SA. Intracellular proton conductance of the hepatitis $\mathrm{C}$ virus $\mathrm{p} 7$ protein and its contribution to infectious virus production. PLoS Pathog. 2010; 6(9): e1001087.

78. Westerbeck JW, Machamer CE. The infectious bronchitis coronavirus envelope protein alters golgi $\mathrm{pH}$ to protect the spike protein and promote the release of infectious virus. J Virol. 2019; 93(11): e00015-19.

79. Lu W, Zheng BJ, Xu K, Schwarz W, Du L, Wong CKL, Chen J, Duan S, Deubel V, Sun B. Severe acute respiratory syndrome-associated coronavirus 3a protein forms an ion channel and modulates virus release. Proc Natl Acad Sci USA. 2006; 103(33): 12540-12545.

80. Chen CC, Krüger J, Sramal I, Hsu HJ, Henklein P, Chen YMA, Fischer WB. ORF8a of SARS-CoV forms an ion channel: experiments and molecular dynamics simulations. Biochim Biophys Acta. 2011; 1808(2): 572-579.

81. Stevens FJ, Argon Y. Protein folding in the ER. Semin Cell Dev Biol. 1999; 10(5): 443-454. 
82. Ron D, Walter P. Signal integration in the endoplasmic reticulum unfolded protein response. Nat Rev Mol Cell Biol. 2007; 8(7): 519-529.

83. Fung TS, Liu DX. Coronavirus infection, ER stress, apoptosis and innate immunity. Front Microbiol. 2014; 5: 296.

84. An S, Chen CJ, Yu X, Leibowitz JL, Makino S. Induction of apoptosis in murine coronavirusinfected cultured cells and demonstration of $\mathrm{E}$ protein as an apoptosis inducer. J Virol. 1999; 73(9): 7853-7859.

85. Yang Y, Xiong Z, Zhang S, Yan Y, Nguyen J, Ng B, Lu H, Brendese J, Yang F, Wang H, Yang XF. Bcl$\mathrm{XL}$ inhibits T-cell apoptosis induced by expression of SARS coronavirus E protein in the absence of growth factors. Biochem J. 2005; 392(Pt 1): 135-143.

86. DeDiego ML, Nieto-Torres JL, JiménezGuardeño JM, Regla-Nava JA, Alvarez E, Oliveros JC, Zhao J, Fett C, Perlman S, Enjuanes L. Severe acute respiratory syndrome coronavirus envelope protein regulates cell stress response and apoptosis. PLoS Pathog. 2011; 7(10): e1002315.

87. Zhang K, Hou Q, Zhong Z, Li X, Chen H, Li W, Wen J, Wang L, Liu W, Zhong F. Porcine reproductive and respiratory syndrome virus activates inflammasomes of porcine alveolar macrophages via its small envelope protein E. Virology. 2013; 442(2): 156-162.

88. Li S, Yuan L, Dai G, Chen RA, Liu DX, Fung TS. Regulation of the ER stress response by the ion channel activity of the infectious bronchitis coronavirus envelope protein modulates virion release, apoptosis, viral fitness, and pathogenesis. Front Microbiol. 2020; 10: 3022.

89. Tan YJ, Goh PY, Fielding BC, Shen S, Chou CF, Fu JL, Leong HN, Leo YS, Ooi EE, Ling AE, Lim SG,
Hong W. Profiles of antibody responses against severe acute respiratory syndrome coronavirus recombinant proteins and their potential use as diagnostic markers. Clin Diagn Lab Immunol. 2004; 11(2): 362-371.

90. Akerström S, Tan YJ, Mirazimi A. Amino acids 15-28 in the ectodomain of SARS coronavirus 3a protein induces neutralizing antibodies. FEBS Lett. 2006; 580(16): 3799-3803.

91. Yuan X, Yao Z, Wu J, Zhou Y, Shan Y, Dong B, Zhao Z, Hua P, Chen J, Cong Y. G1 phase cell cycle arrest induced by SARS-CoV 3a protein via the cyclin D3/pRb pathway. Am J Respir Cell Mol Biol. 2007; 37(1): 9-19.

92. Law PTW, Wong CH, Au TCC, Chuck CP, Kong SK, Chan PKS, To KF, Lo AWI, Chan JYW, Suen YK, Chan HYE, Fung KP, Waye MMY, Sung JJY, Lo YMD, Tsui SKW. The 3a protein of severe acute respiratory syndrome-associated coronavirus induces apoptosis in Vero E6 cells. J Gen Virol. 2005; 86(Pt 7): 1921-1930.

93. Chen IY, Moriyama M, Chang MF, Ichinohe T. Severe Acute Respiratory Syndrome Coronavirus Viroporin 3a Activates the NLRP3 Inflammasome. Front Microbiol. 2019; 10: 50.

94. Siu KL, Yuen KS, Castaño-Rodriguez C, Ye ZW, Yeung ML, Fung SY, Yuan S, Chan CP, Yuen KY, Enjuanes L, Jin DY. Severe acute respiratory syndrome coronavirus ORF3a protein activates the NLRP3 inflammasome by promoting TRAF3dependent ubiquitination of ASC. FASEB J. 2019; 33(8): 8865-8877. 